\title{
Popularyzatorskie audycje radiowe i telewizyjne Alodii Kaweckiej-Gryczowej, czyli o tym jak Wietor pod Krakowem w błocie utknął
}

„[...] Człowiek mądry, oddany swemu zawodowi, sprawie książki i kultury ojczystej, wierny mu w pomyślnych i tragicznych przygodach kraju, z uporem, niekiedy z entuzjazmem (jak po roku 1945) i poświęceniem (jak w latach 1939-1945) budujący warsztaty służące oświacie i nauce społeczeństwa" ${ }^{1}$ - te słowa prof. Alodii Kaweckiej-Gryczowej charakteryzują nie tylko polskich bibliotekarzy ale także ją samą. Znana jako znakomity historyk literatury i kultury, księgoznawca i bibliograf całe swoje życie poświęciła książce i bibliotekom. Jej zasługi dla nauki oraz rozwoju bibliotekarstwa były wielokrotnie doceniane i nagradzane.

Oprócz pracy naukowo-badawczej, a także działań organizacyjnych, bibliotecznych i dydaktycznych prof. Kawecka-Gryczowa starała się popularyzować wiedzę zgodnie ze swoją ideą budowania „warsztatów służących oświacie i nauce społeczeństwa"2. Chętnie zatem brała udział w audycjach radiowych i telewizyjnych, bo jak zaznacza Paulina Buchwald-Pelcowa ${ }^{3}$, nie pomijała żadnej okazji, by mówić i pisać o starych drukach, Bibliotece Narodowej czy w ogóle o książce.

Audycje radiowe i telewizyjne z udziałem Alodii Kaweckiej-Gryczowej uwzględniła w bibliografii jej prac za lata 1926-1990 Anna Maria Wolińska ${ }^{4}$. Bibliografia ta, obejmująca ponad sześćdziesięcioletnią dzia-

\footnotetext{
${ }^{1}$ P. Buchwald-Pelcowa, Wywiad z Prof. Dr Alodia Kawecka-Gryczowa, Przegl. Bibliot., 48:1980, z. 3, s. 225.

2 Tamże.

${ }^{3}$ P. Buchwald-Pelcowa, Bibliotekarka i uczona - Alodia Kawecka-Gryczowa, [w:] W kręgu nauki i bibliotek, (Bibliotekarze Polscy we Wspomnieniach Współczesnych, 3), Warszawa 1993, s. 40.

4 A. M. Wolińska, Bibliografia prac prof. dr Alodii Kaweckiej-Gryczowej za lata
} 
łalność Uczonej, została poszerzona w stosunku do dwu poprzednich ${ }^{5}$ właśnie o wypowiedzi w mediach elektronicznych $\mathrm{z}$ podaniem czasu trwania audycji zgodnie z zapisem w katalogach radia i telewizji. Wolińska zaznacza, że na przestrzeni lat 1974-1985 odnotowano tylko osiem audycji, ale jej zdaniem, wydaje się, że było ich więcej, choć trudno ustalić ile. Autorce zestawienia udało się zidentyfikować tylko tyle. Oprócz tego zamieściła w bibliografii maszynopis słuchowiska radiowego o Hieronimie Wietorze, które na pewno było emitowane na antenie Polskiego Radia, ale bliższych danych o nim Wolińskiej nie udało się ustalić. Udział w audycjach radiowych i telewizyjnych ułożono według chronologii emisji lub nagrania, jeśli daty audycji nie udało się ustalić. A. M. Wolińska umieściła w bibliografii audycje z lat 1974, 1977, 1978, 1979, 1981 i 1985. Wśród nich pięć to programy radiowe, a trzy - telewizyjne.

Pierwszym w zestawieniu jest trwające 19 min. i 50 s. nagranie radiowe zrealizowane przez Redakcję Magazynów i Reportaży programu III PR w kwietniu 1974 roku w ramach audycji Ludzie i Budynki autorstwa Kaliny Kamińskiej. W programie pt. Skarby Pałacu Rzeczypospolitej oprócz Alodii Kaweckiej-Gryczowej wzięły udział Krystyna Muszyńska i Maria Prokopowicz. Rozmowę o najcenniejszych zbiorach BN przeprowadziła dziennikarka Danuta Kaczyńska. Kolejna pozycja to trwająca 46 s. wypowiedź A. Gryczowej na temat współczesnej książki, wyemitowana 5 października 1977 r. w audycji Felieton o tradycjach $i$ wspótczesności drukarstwa polskiego w ramach Magazynu literackiego. W 1978 r. Alodia Kawecka-Gryczowa wystąpiła w telewizji z okazji 50-lecia Biblioteki Narodowej. Audycję, w której opowiada ona przez 3 min. i 4 s., o wojennych losach zbiorów $\mathrm{BN}$ wyemitowano 24 lutego. Kolejny program z tego samego roku umieszczony przez A. M. Wolińską w spisie to Sylwetka prof. A. Kaweckiej-Gryczowej od lat zwiazanej z Biblioteka Narodowa. Życiorys, historia Biblioteki Narodowej i jej losy w czasie okupacji. Został on wyemitowany w radiowym cyklu Sylwetki w audycji Stuchaj nas 7 grudnia 1978 r. i trwał ok. 3 min. Rozmowę z A. Gryczową przeprowadziła Ewa Szymańska, która jest również autorką radiowego reportażu poświęconego budowie nowego gmachu Biblioteki Narodowej z 18 lipca 1979 r. A. Kawecka-Gryczowa i ówczesny dyrektor BN Witold Stankiewicz opowiadają w nim o postępie prac przy budowie gmachu narodowej książnicy na Polu

1926-1990, [w:] Z badań nad dawna książka. Studia ofiarowane profesor Alodii KaweckiejGryczowej w 85-lecie urodzin, t. 1, Warszawa 1991, s. 9-10.

5 Bibliografia prac Alodii Kaweckiej-Gryczowej [cz.1 za lata 1926-1967], „Rocznik Biblioteki Narodowej”, 4:1968 , s. 9-21; Bibliografia... [cz. II za lata 1968-1979], Przegl. Bibliot., 48:1980, z. 3, s. 233-238. 
Mokotowskim oraz wspominają sposoby ratowania księgozbiorów w okresie okupacji hitlerowskiej. Program o nieustalonym przez Wolińską czasie wyemitowano w programie Dzień dobry Warszawo. Natomiast 12 listopada 1979 roku telewizyjny wywiad z A. Gryczową przeprowadziła dziennikarka Grażyna Szcześniak. Podczas 5 min. i 49 s. uczona mówiła o Bibliotece Narodowej, księgozbiorze wilanowskim oraz o swoich pracach naukowych. Przedostatnia $\mathrm{z}$ audycji umieszczonych $\mathrm{w}$ spisie bibliograficznym sporządzonym przez Wolińską, to Rozmowa z historykiem sztuki - znawca książki polskiej. Trwająca 2 min. i 30 s. rozmowa była wstawką w audycji Rozgłośni Warszawsko-Mazowieckiej, którą wyemitowano 6 września 1981 r. Z A. Gryczową o studiach, pracy w bibliotekach, centralnym katalogu inkunabułów, wydawnictwie Polonia typographica, przygotowywanej monografii biblioteki Zygmunta Augusta i bibliofilstwie polskim na tle światowego rozmawiała Bożena Holbrecht. Ostatnia z odnotowanych we wspomnianej bibliografii audycja pochodzi z 18 stycznia 1985 r. i została wyemitowana w programie I PR w Porannych sygnałach dnia. Z okazji 40-lecia wznowienia działalności Biblioteki Narodowej o jej przeszłości, teraźniejszości i przyszłości opowiadali dyrektor Stanisław Czajka, jego zastępcy Stanisław Dobrzański i Wanda Piusińska oraz Alodia Kawecka-Gryczowa. Wolińskiej nie udało się ustalić czasu trwania audycji, a informację o niej podała za Komunikatem [BN] - Sekretariat Organizacyjny BN, 1/85, 1985, s. 4.

A. M. Wolińska przyznaje, że zdaje sobie sprawę, że wypowiedzi dla radia i telewizji z udziałem A. Gryczowej było więcej. Potwierdzenie znajdziemy w artykule Janusza Tazbira, zamieszczonym w „Roczniku Biblioteki Narodowej”, w którym wspomina, jak sam określa, pewne swoje przeżycie stanowiące dla niego wtedy novum: „Gdzieś w latach sześćdziesiątych telewizja postanowiła przygotować poświęcony pałacowi [Krasińskich, J.T.] reportaż, i to dość długi, bo trwający ponad pół godziny. Prof. Kawecka-Gryczowa uznała, że to ja, jako stały bywalec, powinienem go poprowadzić. Uczyniłem to, przyznam, z duszą na ramieniu, albowiem audycja szła na żywo. Co to znaczyło, przekonałem się, kiedy zaczęto dawać mi znaki zza kamery, abym już kończył, bo przekraczamy czas antenowy. Jakoś z tego wybrnąłem, ale przy walnej pomocy pani Alodii, która potrafiła zachować przed kamerą niezmącony spokój. Miało się wrażenie, że od wielu już lat występowała w telewizji. Przypatrywałem się temu z wielkim podziwem"6. s. 17.

${ }^{6}$ J. Tazbir, Wokót Biblioteki Narodowej, „Rocznik Biblioteki Narodowej”, 35:2003, 
Można zatem wyciągnąć wniosek, że A. Gryczowa czuła się swobodnie przed kamerą i nie okazywała tremy. Jednocześnie J. Tazbir nadmienia, że chodziło o program z lat sześćdziesiątych. Zapewne miał na myśli reportaż z 2 grudnia 1966 pt. W Bibliotece Rzeczypospolitej. Jego maszynopis znajduje się w dziale rękopisów BN w teczkach będących spuścizną po A. Gryczowej. Teczka o sygn. Akc. 17978 zawiera maszynopisy, rękopisy jedenastu audycji radiowych i telewizyjnych od 1950 do 1968 roku, w tym słuchowisko radiowe o Hieronimie Wietorze oraz dwie niedatowane,

Najwcześniejsze jest właśnie słuchowisko radiowe o Wietorze, które A. M. Wolińska umieściła w swojej bibliografii z zaznaczeniem, że daty emisji na antenie Polskiego Radia, reżysera, ani obsady nie zdołano odnaleźć, a taśmę $\mathrm{z}$ nagraniem skasowano w latach sześćdziesiątych. W materiałach znajduje się sześć maszynopisów słuchowiska, podpisanych przez Alodię Kawecką-Gryczową i datowanych na 28/29 czerwca 1950 r. oraz rękopis tegoż. Część z nich ma tytuł Hieronim Wietor - przyjaciel humanistów, opiekun polskiego piśmiennictwa, a część tylko Hieronim Wietor - przyjaciel humanistów. Na jednym z maszynopisów znajduje się nagłówek Rozgłośni Krakowskiej Polskiego Radia, Działu Artystycznego, Redakcji literackiej. Niestety oprócz informacji, że nagranie jest na taśmie, nie ma ani terminu emisji ani czasu trwania audycji. Akcja słuchowiska rozgrywa się jesienią 1517 r. Występują: Jeronim Bottcher (Wietor), Pachołek Rudolf Agrykola (przyjaciel Wietora), Mikołaj Jordan (wielkorządca krakowski), Anna z Jarosławia z rodu Tarnowskich (żona Jordana). Czeladnik I, Czeladnik II, Barbara (żona Wietora). Pierwsza część słuchowiska rozpoczyna się sceną, gdy Wietor w drodze $\mathrm{z}$ Wiednia do Krakowa utknął w błocie tuż przed miastem. Z opresji ratują go Mikołaj Jordan wraz z żoną. Drukarz tłumaczy napotkanym pp. Jordanom powody, dla których postanowił przenieść swój warsztat (znajdujący się na ugrzęzłych w błocie wozach) nad Wisłę. W rozmowie o Odrodzeniu, padają nazwiska m.in. Mikołaja Czepiela, Piotra Tomickiego, Jana Dantyszka oraz Erazma z Rotterdamu. Wietor wspomina także krakowskich drukarzy - Hallera i Floriana Unglera. Zamiarem Wietora jest wydawanie nowych łacińskich i greckich gramatyk, łacińskiej poezji i uczonych traktatów. Anna Jordanowa przyznaje, że nie zna

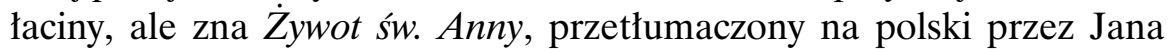
z Koszyczek, i zachwala przy tym także umiejętności Biernata z Lublina. Wietor mówi natomiast o tym, że chciałby znaleźć tłumacza bajek Ezopa. Dalsza rozmowa dotyczy zbliżającego się ślubu Zygmunta Starego z Boną i żniwach dla drukarzy z tego powodu. Wietor mówi, że zatrzy- 
ma się w Krakowie u Marka Scharffenberga, swojego kolegi. Po tym, spiker opowiada o uruchomieniu przez Wietora warsztatu w 1518 r., o wydaniu w 1520 r. Żywota św. Anny w przekładzie Jana z Koszyczek (drugiej po Raju dusznym książce w języku polskim, której jedyny zachowany egzemplarz został spalony przez hitlerowców), a także o ponownym wydaniu w 1521 Raju dusznego tłumaczonego przez Biernata z Lublina oraz w tym samym roku Rozmów, które miat król Salomon mądry $z$ Marchottem grubym a sprośnym dedykowanych Annie Jordanowej ze wspomnieniem spotkania pod Krakowem. Dedykacja umieszczona przez Wietora jest następująca:

WIELMOŻNEJ I ŚLACHETNEJ PANIEJ ANNIE Z JAROSŁAWIA, KASZTELANCE WOJNICKIEJ, SPISKIEJ, OŚWIĘCIMSKIEJ, ZATORSKIEJ STAROŚCINEJ ETC. WIELKIEJ RZĄDŹCZYNEJ KRAKOWSKIEJ, PANIEJ MOJEJ NAŁASKAWSZEJ, JERONIM WIETOR, IMPRESSOR, SŁUŻBE SWĄ POKORNĄ I UKŁONEM POWIADA. Gdym przeszłych lat, wielmożna pani Anno wojnicka, pani moja łaskawa, tu, w ty strony, do Polski, przyszedł, nie tak dla chciwości bogactw albo mienia, ale więcej dla czci a sławy pospolitej tego sławnego królestwa polskiego, dlatego myśląc a chcąc niejaką wdzięczność a pożytek uczynić Polakom, myśliłem mowę polską i księgi polskie moim nakładem wybijać. Która rzecz aczkolwie wielką trudność w sobie miała a ukazowała, a wszakoż ja, zjęt chciwością a świebodnością ziemie tej polskiej, znamienitej a wszech naobfitszej, tymem więtszą chciwość miał. Ale jeszcze, gdy częstokroć słudzy twej wielmożności przychodząc do mnie, cni słudzy cnotliwej paniej, ode mnie żądali, iżbych polskim pismem nieco wybijał; gdyżem poczuł tak wielką żądzą tych twoich sług albo wielmożności waszej, nie mogłem się wstrzymać, bych w tym wdzięczności nie ukazał wielmożności waszej, dla waszej osobliwej cnoty, którą wszytkim ukazujecie, częścią też dla wielkiej łaski a cnoty męża waszego naślachetniejszego, a króla jego miłości, pana naszego namilościwszego, pana radnego. Bo ona łaska a lutość pana jego miłości twego w dobrej mi pamięci jest, bo gdym jechał do Polski, a będąc blisko Krakowa, tamem z rzeczami swoimi w wielkiem błocie zawiąznął, jego miłość pan twój, w ten czas jadąc w drogę, wolał sobie zmieszkać, a mnie z błota wyrwać. O panie łaskawy, o panie miłosierny a lutościwy! Nie mam ci czym tej lutości odsłużyć albo oddać, ale tym pismem a wybijaniem imię twoje a twój nad ubogim cnotliwy uczynek chcę na wieczność dać. Przeto już ja, zjęt tą wielką chciwością, gdyżem zgotował litery a wszytki ku pismu potrzeby, myśląc co bych miał tak krotofilnego naprzód wybijać, wziąłem przed się śmiesznego a krotofilnego Marchołta gadanie z Salomonem, który moim własnym nakładem, przez Jana bakałarza z Koszyczek, też sługę twego pokornego, wyłożon jest w polskie z łaciny. Którego, wielmożna pani wojnicka, wielmożności twej polecam i jako mówią pospolicie, poświącam i oddawani, nie dlatego, iżby ty nie była dostojniejsza więtszego a znamienitszego daru, ale iż na ten czas, dla mojej żądze odsłużenia wielikiej, którą mam ku 
waszej wielmożności, nie miałem nic takiego, waszej wysokiej personie dostojnego. Przeto, miłościwa gospodze, wielmożna pani Anno wojnicka; przyjmi tego, teraz ku czci a sławie na potem twojej, Marchołta, z wesołością a z wdzięcznością, wrychle wielmożność twoja wićle mych rzeczy, ważnych ku czci a chwale twojej, poślubione masz mieć. A gdy to według twej wysokiej a ważnej ślachetności przyimiesz, Jeronima z Wiądnia, cudzoziemca, impressora i Jana bakalarza z Koszyczek, wykładacza, pokornych sług swoich nie racz zapominać, to będziesz raczyła uczynić, jako pani miłościwa, łaskawa a z rodu wysokiego pana krakowskiego i z wysokiej cnoty poszła. Zatem się miej dobrze, pani miłościwa a lutościwa! Dan list z domu naszego we wtorek przed świętym Tonią 4 apostołem, lata bożego narodzenia $1521^{7}$.

Spiker dodaje jeszcze informację o Żywocie Ezopa Fryga z Przypowieściami w swobodnej przeróbce Biernata z Lublina. Część druga słuchowiska toczy się w krakowskiej drukarni Wietora przy ul. Gołębiej w roku 1542. Wietor zapewnia żonę, że Polacy nie są gorsi od Francuzów i Włochów, którzy wydają druki w ojczystych mowach. Żona natomiast przypomina $\mathrm{mu}$, że przez 25 lat pracy dorobił się za zasługi kamienicy na warsztat i tytułu typografa kancelarii królewskiej, a Rej z Nagłowic chce właśnie u niego wydać Krótka rozprawę między panem, wójtem a plebanem. Wietor, odpowiada żonie, że odesłał Reja do Macieja Scharffenberga ze względu na ostrość wypowiedzi rozprawy i mogące wynikać z tego kłopoty. Słuchowisko kończy się informacją spikera, że Wietor zmarł w 1546 r., a drukarnię prowadziła jego żona, która wyszła następnie powtórnie za mąż za czeladnika Łazarza Andrysowica, pod którego firmą po śmierci Barbary drukarnia działała nadal. Z czasem poprowadził ją ich syn, Jan Januszowski, najwybitniejszy drukarz II polowy XVI w.

W przypadku kolejnej audycji radiowej pt. W tłoczni krakowskiej Pana Wietora, problem stanowi ustalenie daty jej emisji: czy nastąpiło w roku 1958 czy też w 1959? W teczce znajdują się bowiem dwa egzemplarze maszynopisu oraz rękopis. Jeden z maszynopisów zapakowany jest w kopertę z pieczęcią Komitetu do Spraw Radiofonii, Polskie Radio, Zespół Programu Krajowego, Dział Programów Oświatowych i zaadresowany do prof. Gryczowej. Oprócz scenariusza audycji znajduje się tam także kartka, z której wynika, że audycja powstała, z okazji Międzynarodowej Wystawy Książki w Lipsku, prezentującej dorobek Krajów Demokracji

7 Podstawą tekstu jest wydanie: Proza polska wczesnego renesansu 1510-1550: [teksty], oprac. Julian Krzyżanowski, Warszawa 1954, s. 83-120 - http://literat.ug.edu.pl/march/dedyk.htm [dostęp 8 listopada 2010]. 
Ludowej, na którą to BN przygotowała wystawę, a jednym z eksponatów jest szesnastowieczny druk z tłoczni Hieronima Wietora ${ }^{8}$. Przygotowana z tej okazji pogadanka ma przybliżyć postać drukarza. Maszynopis audycji opatrzony jest nagłówkiem Redakcji Audycji Historycznych programu I, z datą 30 lipca 1959 r. oraz godziną emisji - 10.00-10.10. Redaktorem była K. Żebrowska. Natomiast na kolejnym maszynopisie, W ttoczni krakowskiej Pana Wietora, znajduje się dopisek: „radio 18.V.1958 godz. 13.20, II program 15 min”. Dołączona jest też kartka $\mathrm{z}$ informacją, że 21 czerwca w sprawie pogadanki w radio dzwoniła Hala Kiepurska. Treść maszynopisów jest taka sama. Być może pogadankę wyemitowano dwa razy, a może w rezultacie emisja odbyła się nie w 1958 r., a w 1959 r. W audycji W tłoczni krakowskiej pan Hieronima Wietora A. Gryczowa zarysowuje sytuację w ówczesnej Polsce, w tym sprzyjające warunki polityczno-gospodarcze dla rozwoju kultury w duchu humanizmu i reformacji. Następnie przechodzi do przedstawienia sylwetki Hieronima Wietora i jego zasług dla polskiego drukarstwa. Wietor, który w młodości studiował w Akademii Krakowskiej, gdzie zetknął się humanizmem za sprawą wykładów Pawła z Krosna, i szukając zarobku oprawiał książki i poznał rzemiosło drukarskie u Jana Hallera [wyjechał w 1510 roku do Wiednia, przyp. aut.]. Przybył ponownie do Krakowa w 1517 r. zachęcony zapewne przez Marka Scharffenberga i zbliżającym się ślubem Zygmunta Starego z Boną. Z pod prasy Wietora wychodziły humanistyczne podręczniki, wydania tekstów literatury klasycznej, wzory eleganckiej łaciny. Pierwszym jego drukiem była wydana w 1518 głośna książeczka pt. Skarga pokoju (Quaerela pacis) Erazma z Rotterdamu. Wietor posiadając czcionki lacińskie, hebrajskie i greckie, wydał pierwszą książkę po grecku. Wydawał także od 1520 r. książki w języku polskim, począwszy od Żywota św. Anny i Raju dusznego. Umierając w 1546 r. miał w swoim dorobku ponad 550 pozycji, łącznej objętości około 3000 arkuszy, co świadczy o jego przodującej roli w ówczesnym ruchu wydawniczym. Wietor, który pisał sam o sobie - wmieszkany a nie urodzony Polak - odegrał w zakresie propagowania piśmiennictwa narodowego niepoślednią rolę. W zakończeniu, zgodnie ze scenariuszem audycji, A. Gryczowa dodaje: „Dochodzą nas poprzez

${ }^{8}$ Chodzi zapewne o Żywot Wszechmocnego Syna Bożego Pana Jezu Krysta, [autor wersji polskiej Baltazar Opeć], Kraków, Hieronim Wietor, [po 5 V] 1522. $2^{\circ}$ (28 x 19,5 cm) BN SD XVI. F. 3. Rzeczony egzemplarz to najstarsza zachowana w całości książka drukowana w języku polskim, uznawana za najwytworniejszy i najokazalszy druk z oficyny Wietora. Jest jednym z pięciu egzemplarzy zachowanych w bibliotekach polskich, pochodzi ze zbiorów Biblioteki Ordynacji Zamojskiej. 
wieki słowa Hieronima, że podejmował prace «z wielkim potem a skonaniem swoim», aby «wżdy polskie księgi były, ażeby Polacy mądrości mnożyli», «dla czci a sławy pospolitej tego sławnego Królestwa Polskiego»".

Jedną z form popularyzacji dziejów książki przez Alodię KaweckąGryczową była działalność wystawiennicza, której poświęcała dużo uwagi i czasu. Do najwspanialszych wystaw, przygotowanych pod jej nadzorem w BN, należą: Arianie w Polsce (1958 r., powtórzona rok później w Pradze), Czterysta pięćdziesiąt lat drukowanej książki polskiej (1963), Ksią̇ka polska przez wieki (1965, prezentowana też w Antwerpii), Ksią̇ka polska wczoraj $i$ dziś (1974). Z okazji wystawy Arianie w Polsce A. Gryczowa przygotowała pogadankę Działalność wydawnicza Braci Polskich (dopisek ołówkiem - zwanych arianami). Na maszynopisie znajduje się dopisek „9.II.1958 Progr. I godz. 14.45-15 red W. Nowosławska”. A. Gryczowa przedstawiła historię osiedlenia się arian w Polsce, ich działalność wydawniczą w Krakowie i Rakowie, problemy Aleksego Rodeckiego związane z prześladowaniem religijnym oraz przekazanie Rakowskiej oficyny Sebastianowi Sternackiemu. Wspomina o tzw. Katechizmie Rakowskim, wydanym w 1605 r. (4 lata później przetłumaczonym na łacinę), który zyskał sławę w całej Europie. Sternacki wydał w ciągu 36 lat 200 tytułów (jedno z przodujących miejsc w dziejach polskiego drukarstwa I połowy XVII w.) - jak podkreśla A. Gryczowa, o nowoczesnej, zgrabnej postaci dorównującej poziomem wydawnictwom zagranicznym, nawet holenderskim, uchodzących za najlepsze tego okresu. Pogadanka kończy się informacją o rozgromieniu Rakowa wyrokiem sejmowym, próbach dalszej działalności drukarskiej i rozproszeniu po całej Europie, po zmuszeniu arian do opuszczenia Polski.

Z 1963 roku pochodzą dwa maszynopisy reportaży radiowych, które jak wynika $\mathrm{z}$ dołączonej kartki zostały przesłane A. Gryczowej przez p. Manteufflową ${ }^{9}$ w celach dokumentacyjnych. Pierwszy z nich pt. O działalności pierwszych drukarni autorstwa Stanisławy Nożanki wyemitowano 6 maja w audycji Warszawska Fala z okazji otwarcia kiermaszu przed Pałacem Kultury i Nauki inaugurującego Dni Oświaty, Książki i Prasy. A. Gryczowa opowiada w nim o najcenniejszych skarbach BN - pierwszych wydaniach: Krótkiej rozprawy między trzema osobami panem, wójtem a plebanem Mikołaja Reja (Kraków 1543), a także Andrzeja Frycza Modrzewskiego Commentarii de Republica emendanda

${ }^{9}$ Zapewne Marię Manteufflową, ówczesną kierowniczkę Zakładu Informacji Naukowej BN. 
(Kraków 1551) z uratowanymi składkami A-G skonfiskowanej przez cenzurę kościelną księgi IV O Kościele (Liber de ecclesia), a także o pierwszych drukarniach warszawskich od Walentego Łapki (później po uzyskaniu szlachectwa zwany Łapczyńskim), przez Jana Rosowskiego i Piotra Elerta aż po Michała Grölla i Piotra Dufoura. Drugi reportaż tej samej autorki z 29 maja powstał z okazji wystawy w BN 450 lat ksiązki drukowanej w pałacu Krasińskich. A. Gryczowa oprowadza po wystawie i opowiada o najcenniejszych eksponatach np. Raju dusznym Biernata z Lublina, XVI wiecznych elementarzach, słowniku Lindego.

Również z okazji Dni Oświaty, Książki i Prasy, Międzynarodowych Targów Książki oraz 600-lecia polskiego księgarstwa powstał program telewizyjny Na pergaminie i na papierze. W teczce A. Gryczowej znajduje się scenariusz tej audycji datowany na 17 maja 1964 r., w którym oprócz niej samej wystąpił Piotr Hniedziewicz, senior polskich księgarzy, ówczesny kierownik Księgarni Literackiej na Rynku Starego Miasta. Audycja, zgodnie ze scenariuszem, rozpoczynała się przedstawieniem sposobów i metod jakimi człowiek utrwalał swoje myśli i przekazywał je innym. Wykorzystano przy tym ilustracje pierwotnych form pisma obrazkowego, hieroglificznego i klinowego. Następnie prowadząca program Danuta Szczerska zadała pytanie A. Gryczowej o historię polskiej książki. Ze scenariusza wynika, że A. Gryczowa miała na odpowiedź 15 minut. $\mathrm{Z}$ rękopisu towarzyszącemu temu maszynopisowi można wywnioskować, że przygotowała wcześniej odpowiedź oraz odpowiednie druki, które posłużyły za ilustracje. Piotr Hniedziewicz mówił natomiast o dziewiętnastowiecznych księgarzach, szkoleniu współczesnych oraz o warszawskim Klubie Księgarza. Program zrealizowała Alicja Śleżańska.

Kolejna z audycji radiowych wyemitowana w Warszawskiej Fali dotyczyła Biblioteki Narodowej i datowana jest na 27 kwietnia 1965 r. Z treści maszynopisu wynika, że A. Gryczowa mówiła o różnorodnej działalności BN z okazji wystawy prezentującej kilkadziesiąt cennych obiektów zgromadzonych przez 20 powojennych lat.

W materiałach będącymi spuścizną po A. Gryczowej znajdują się wersje robocze scenariusza reportażu telewizyjnego $W$ Bibliotece Rzeczpospolitej. Jeden z nich datowany jest na 2 grudnia 1966 (na kartce odręcznie napis: „Reportaż z BN Pl. Kras. 2. XII. 1966”) i zapewne to o nim wspomina J. Tazbir. Oprócz niego udział w nim wzięli A. Gryczowa, Zbigniew Daszkowski ówczesny wicedyrektor BN oraz Witold Stankiewicz. Według scenariusza reportaż zaczynał się czytaniem przez aktora listów Józefa Andrzeja Załuskiego z 1736 i 1744, w których informuje on o kupnie kamienicy Daniłowiczowskiej i zamiarze założenia w niej 
Biblioteki Publicznej oraz o pomyśle zatrudnienia „rozumnego” bibliotekarza. Następnie podczas wędrówki po pałacu zaprezentowane zostały zbiory specjalne, ich historia oraz historia samej BN. Audycja miała, zgodnie ze scenariuszem, zakończyć się apelem o wzbogacanie BN cennymi materiałami świadczącymi o kulturze polskiej.

Ostatni z maszynopisów z teczki A. Gryczowej datowany jest na 5 marca 1968 roku i również dotyczy BN. Nie przedstawia w nim historii biblioteki i jej zasobów, tylko mówi o bieżących kłopotach, m.in. o tym, że część zbiorów musiano umieścić w podziemiach pałacu, zupełnie nieodpowiednich i zawilgoconych; o złym stanie przechowywania książek zabytkowych, o ujemnie wpływającym na budynek, urządzonym przed pałacem, parkingu. Sprawa tego ostatniego musiała być poruszana w radiu już wcześniej, bowiem z maszynopisu wynika, że A. Gryczowa dziękuje przy sposobności Polskiemu Radiu za energiczne poruszenie swego czasu tej bolączki. Apeluje także do konserwatorów zabytków o zwrócenie bacznej uwagi na stan Pałacu Rzeczypospolitej. Następnie przechodzi do sprawy konserwacji zabytków książkowych, która, jej zdaniem leży odłogiem - na 140 tys. woluminów jedna trzecia wymaga mniejszych lub większych zabiegów konserwatorskich, a niewielka pracownia konserwatorska BN może poddać zabiegom ok. 40 książek w ciągu roku. Jako przyczyny tego stanu rzeczy A. Gryczowa wymienia: zbyt małą liczbę etatów, niewielką powierzchnię lokalową oraz brak specjalistów.

W papierach po Alodii Kaweckiej-Gryczowej znajdują się także materiały do dwóch audycji radiowych, które jednak nie są datowane. Pierwsza to Dawne pieśni wielkopostne, zachowana w postaci maszynopisu oraz rękopisu z adnotacją „dla p. Niesiołowskiej” ${ }^{10}$. Ze scenariusza wynika, że audycja składać się będzie z recytacji poszczególnych pieśni oraz pogadanki. Niestety nie wiadomo zarówno, kto recytował pieśni, ani czy w audycji wystąpiła sama A. Gryczowa. Program zaczyna się od omówienia pieśni pochodzących z pocz. XV w., które albo szeroko opowiadały o Męce Pańskiej, albo miały charakter kontemplacyjny, pobudzały do rozpamiętywania grzechów, wzywały do żalu. Najstarsza pieśn wielkopostna powstała pod wpływem śpiewu liturgicznego, a zapisana została po raz pierwszy ok. 1420 r. i nazwana Godzinkami o Męce Pańskiej, ze względu na opowieść o Męce Pańskiej w kolejności godzin Pasji.

Jezus Chrystus Bóg człowiek mądrość ojca swego

Po czwartkowej wieczerzy czasu jutrzennego...

\footnotetext{
${ }^{10}$ Anna Arendt-Niesiołowska.
} 
Następnie przedstawione zostały przemiany formy pieśni wielkopostnych na przestrzeni wieków od XVI do XVIII, kiedy to przybrały formę „Gorzkich żali”. Wprowadziło je Bractwo św. Rocha w początkach XVIII wieku zamiast starych, wystawnych dewocji łacińskich. Do maszynopisu audycji dołączono teksty pieśni.

Ostatnia $\mathrm{z}$ audycji to Losy ksiag rachunkowych w rękopisie i z adnotacją „radio”. Jednak są to luźne kartki wymieszane z notatkami autorki, dotyczącymi badań K. Piekarskiego nad makulaturą, i jej zapiski o odnalezionych wśród wybrakowanego papieru fragmentach dzieł. Natomiast same losy ksiąg rachunkowych to ogólnikowe notatki dotyczące archiwum królewskiego - Archiwum Koronnego Krakowskiego i Archiwum Koronnego Warszawskiego.

Audycje telewizyjne i radiowe z udziałem Alodii Kaweckiej-Gryczowej powstawały z okazji wystaw organizowanych w BN np. 450 lat ksią ki drukowanej (1963), Działalność wydawnicza Braci Polskich (1958), jubileuszy np. 40-lecie Biblioteki Narodowej (1985), Międzynarodowych Targów Książki np. W tłoczni krakowskiej pana Wietora (1959), Dni Oświaty, Książki i Prasy np. O dziatalności pierwszych drukarń (1963), wydarzeń związanych z BN - budową nowego gmachu - reportaż Ewy Szymańskiej z 1979 r. Niektóre z nich inicjowane były zapewne przez samą A. Gryczową, zwłaszcza te dotyczące bieżących problemów BN (notatki do audycji z 5 marca 1968).

Niestety informacje zawarte w maszynopisach i rękopisach audycji radiowych i telewizyjnych, zachowanych w teczkach ze spuścizną, nie pozwalają na ustalenie pełnych danych odnośnie poszczególnych programów dat emisji, czasu trwania, realizatorów. W niektórych przypadkach są to bowiem odręczne uwagi napisane ręką autorki - np. „15 minut”, „radio”.

W teczce nie ma scenariuszy audycji, które wykazała w swojej bibliografii A. M. Wolińska, oprócz jednej - słuchowiska o Wietorze z 1950 r. Wszystkie pochodzą z lat 50. i 60. i zapewne dlatego nie zostały ujęte $\mathrm{w}$ archiwach radia i telewizji. Być może nagrania radiowe, tak jak słuchowisko o Wietorze, zostały skasowane lub jeśli nadawane były w audycjach informacyjnych, w ogóle nie były nagrywane. Podobnie może wyglądać sprawa w przypadku audycji telewizyjnych ( $N a$ pergaminie $i$ na papierze z 1964 r., W Bibliotece Rzeczypospolitej z 1966 r.).

Zarówno maszynopisy jak i rękopisy w większości opatrzone są licznymi poprawkami i uwagami dającymi możliwość śledzenia kolejnych etapów pracy nad poszczególnymi scenariuszami i wypowiedziami.

W teczce znajdują się także karty katalogowe, na których A. Gryczowa wypisywała pozycje książkowe z sygnaturami, służące do ilustracji au- 
dycji lub będące pomocnymi przy przygotowaniu wypowiedzi. Po tytułach łatwo się zorientować, czego dotyczyły audycje, m.in. Jana Kochanowskiego, Konstytucji 3 maja, starych encyklopedii, starych druków muzycznych czy starych opraw. Jednak nie wiadomo czy wszystkie programy były z jej udziałem. Kartoteka zawiera następujące informacje: „Biblioteka Patria” 3.II.78; p. Gliszczyńska TV „400-lecie drukarstwa”; Interpress p. Ochnio 18.I.78; M. Sosnowski „Pegaz” TV 7.IX.1978; p. Micińska „Dialogi z przeszłości” TV 25.IV.78; red. Kozłowska k. stycz. 7.IV.78; „Dziennik” TV 9.IV.79; „Dziennik” TV „Stare encyklopedie” 23.III.79; TV 2 XI 78, TV Red. Publicystyki Kulturalnej Irena Tomaszewska 2.X.78; „Wtorek Melomana” 27.XI.79; „Skarbiec” TV 11.XI.78; „Skarbiec” TV 10.XI.78; „Skarbiec” TV 19.XII.78; „Skarbiec TV” 30.IX.79 Komisja Edukacji Narodowej; „Dziennik” TV p. Gliszczyńska 30.IV.79; „Dzieje drukarstwa” Wytwórnia Czotówka ok. 70 eksponatów III kw. 79; „Horyzonty Techniki” p. Medera 27.VI.78 oprawy. Z notatek i treści samych audycji można wnioskować, że być może audycji radiowych i telewizyjnych było więcej. Wskazuje na to kartka podpisana przez p. Manteufflową dołączona do przesłanych A. Gryczowej scenariuszy dwóch audycji z 1963 r. oraz treść notatek do audycji o bieżących problemach BN z 1968 r. a także wspomniana kartoteka ze spisami książek. Ponowne zestawienie audycji radiowych i telewizyjnych z udziałem A. Kaweckiej-Gryczowej to zadanie dla bibliografów wymagające żmudnej i cierpliwej pracy.

\section{Summary}

"How the printer Wietor nearly drowned in mud near Cracow": Popularisation of Book History on Radio and TV by Alodia Kawecka-Gryczowa

In accord with her concept of constructing 'workshops for enlightening and educating the society' Professor Alodia Kawecka-Gryczowa was very keen on popularizing book history. Little wonder then that she let no opportunity pass to talk on the radio or the television about old prints, the National Library, or about books in general. The bibliography of her works prepared by A. M. Wolińska includes among other eight such programmes for the years 1974-1985, although Wolińska notices that, there must have been more. This statement found substantiation in the 'Grycz papers' bequeathed to the National Library - the folder Akc. 17978 holds typescripts of 
eleven radio and television programmes broadcast between 1950 and 1968, and two other with no dating. Unfortunately, the data provided by these papers does not allow a for more detailed historical description of these programmes, their dates of emission, length and producers. Neither can one find in this folder the screen-plays of the programmes listed by A. M. Wolinska, with the sole exception of the radio broadcast devoted to the printer Wietor, emitted in 1950. All the other materials come from the nineteen-fifties and the nineteen-sixties, which explains why they are not present in the Archives of the Polish Radio and Television - being either never recorded, or the tapes had been destroyed.

The aforementioned folder also contains a number of catalogue cards on which one finds titles and shelf-marks of books, which were utilized by Gryczowa in her cooperation with the radio and television, although it is difficult to ascertain that all these books were gathered for programmes, in which Professor Gryczowa took part personally. 


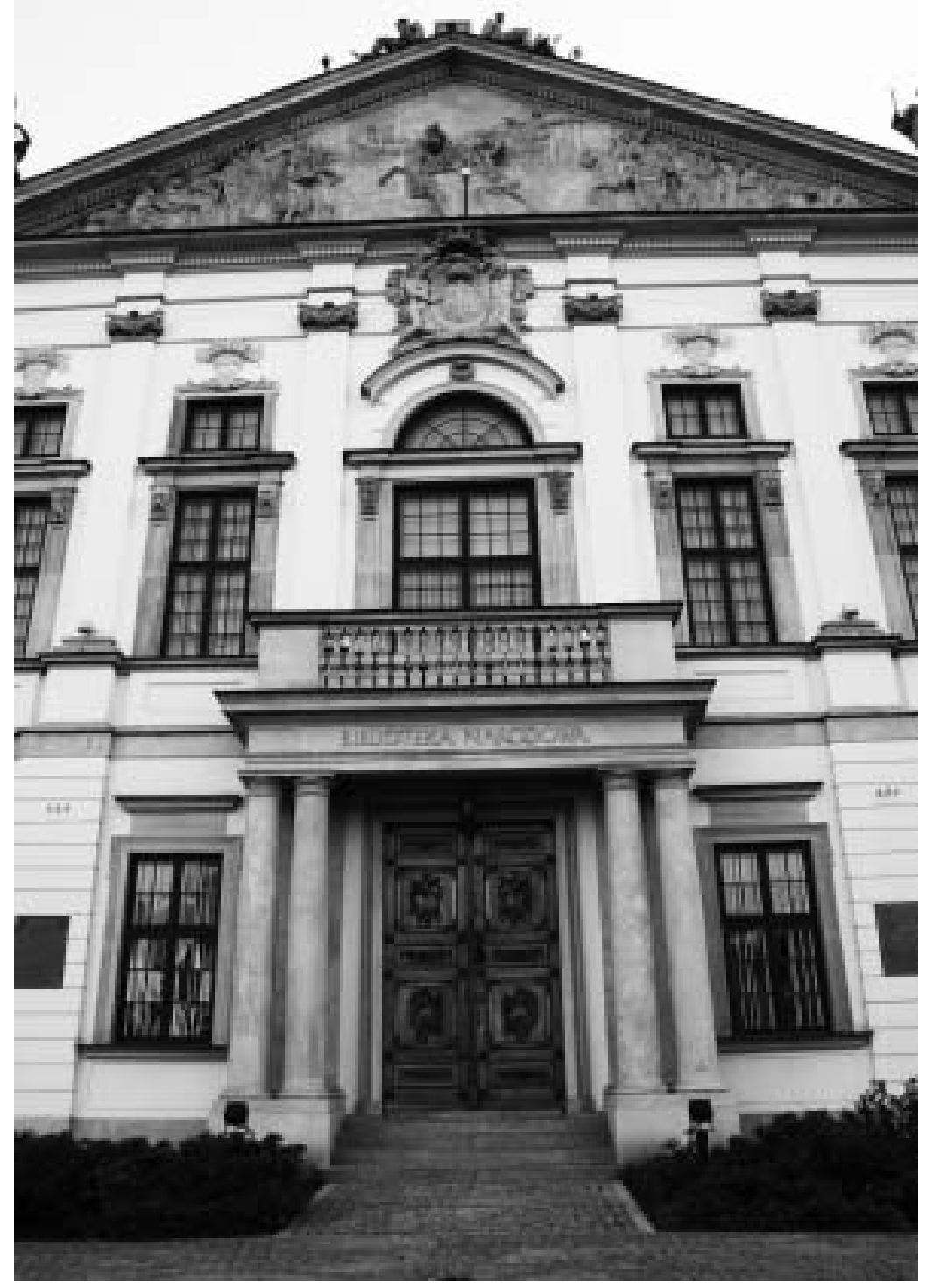

Pałac Rzeczypospolitej, siedziba Oddziału Zbiorów Specjalnych BN (fot. M.K. Miszczuk) 